\title{
An Immigration Success Story
}

\author{
Jackson Toby
}

Nearly thirty years ago I was lecturing to my course ("Introduction to Sociology") of about 250 students at Rutgers University when I caught one student's eyes. Nearly all of the others were staring at their notebooks as they took notes; his eyes were looking directly at me.

A week or so later he came up to speak to me after class. He explained that he could not get to most of the recitation sections taught by one of my six graduate assistants because all of the sections met on Fridays, when the soccer team was usually traveling. (Lino was the co-captain of the team.) He assured me that he would make up the work. I listened skeptically. What about section quizzes? Lino did very well in the class. His A or B was achieved largely on the basis of my difficult multiple-choice mid-terms and final exams that some students failed.

During that semester, Lino came several times to my office hours to ask questions about sociology, where he was usually my only student visitor. Like many Rutgers students at that time, he was the first member of his family to attend college. He was also foreign-born; his illiterate Italian parents immigrated with their two sons to the United States through New York harbor when he was three years old to give him and his older brother opportunities they could not get in Montazzoli, a rural village about a hundred miles east of Rome without a newspaper, a doctor, or a library. Lino had not seen a book until he went to school in America.

A semester or two later, Lino came to my office hours; he had left college before graduating and had been playing professional soccer. However, he decided that he wasn't a good enough player to become another Pelé; he wanted to graduate and go to law school. At that time law schools were in tremendous demand, and the competition for admission was fierce. Unfortunately, although he had a solid academic record, making the Dean's Honor list several times, his

Jackson Toby is professor emeritus of sociology at Rutgers University, where he was director of the Institute for Criminological Research; jtoby@scarletmail.rutgers.edu. His most recent book is The Lowering of Higher Education in America (Praeger 2009). Toby's "Free College and the Problem of College Readiness," also appears in this issue of $A Q$. 
Grade Point Average (GPA) was dragged down by a poor freshman year. Though he started seriously applying himself in his sophomore year, neither his grades nor his Law School Aptitude scores were high enough to get into law school. "What can I do?" he asked. I offered him the only advice I could: "Show a law school that despite less-than-top grades, you have another talent that makes you an outstanding law-school prospect.” He didn't think that his soccer skill would help much with a law school admissions committee. "You can try to publish an article about soccer in a major newspaper; college seniors rarely get published in major newspapers." Lino didn't believe that he could write well enough to get published. I suggested a strategy. Keep revising. By the fifth or the tenth revision, he might have a chance. I offered to criticize his revisions if he were willing to make them. He agreed and made many revisions.

The story he told in his article, "The Myth of the Dumb Jock," was only partly about soccer; another subject was hard work, a lesson Lino learned from his hard-working parents. Here is a paragraph from his article:

In September 1990 our team was in Williamsburg, Va., playing in the College of William and Mary's tournament. We won our first game against Old Dominion, 1-0, and also beat William and Mary, 2-0. We were overall champions of the tournament and I was named the Most Valuable Player. Instead of talking with teammates and celebrating the victory on the way home that night, I spent six hours reading and doing my homework amid a group of jubilant and excited athletes. Similarly, after beating Dartmouth in 1990's NCAA tournament, I had two choices: have a great time at the Scarlet Pub criticizing and praising our team's effort with teammates and coaches, or study. That night I studied, even after rationalizing and justifying false reasons to postpone it.

Lino submitted his article to several newspapers; all rejected it. Finally, he submitted it to the Wall Street Journal, which published it on February 2, 1993. On the day it appeared, Lino's father was working at his regular janitorial job at a New Jersey headquarters of AT \& T. A manager approached him and asked him whether he was related to the author of the article in the newspaper, Lino DiCuollo. “Yeah, he's my son.” Lino's father had not known that the article was to be published, and he could not read it. But he made 100 copies of it on an AT \& T copier and took them home. 
Lino was admitted to the Rutgers Law School at Camden; I went to Camden for his graduation two years later. Lino is fifty-one years old now; he was for many years a top executive at Major League Soccer; he is married and has three children.

I continue to be proud of him. 